\section{OPENING OF THE NEW PHYSIOLOGICAL LABORATORY AT CAMBRIDGE.}

\section{Honorary Degrees Conferred.}

THE Public Orator (Sir John Sandys) delivered the following speeches in presenting to the Chancellor (Lord Rayleigh) the several distinguished recipients of the honorary degrees conferred on the occasion of the opening of the new physiological laboratory at Cambridge on June 9 :-

Hon. LL.D.

H.R.H. Prince Arthur of Connaught, K.G., K.T., G.C.V.O.

Gratias, quae Principi feliciter ad nos advecto patria in lingua feliciter redditae sunt, etiam Academico in sermone eidem libenter reddimus. Salutamus Victoriae Reginae et Principis Alberti, Cancellarii nostri, nepotem acceptissimum, Ducis Arthuri filium unicum, Principem patriae devotissimum, Principem in luce publica plurima cum laude versatum. Regis nostri in nomine olim ad extremam Orientis oram honoris causa plus quam semel missus est; Regia artium in Academia nuper pictoribus nonnullis consilia sobria, consilia sana, commendavit; nostram denique ad litterarum et scientiarum Academiam hodie allatus, aedificium novum physiologiae studiis dedicatum auspiciis optimis mox inaugurabit. Physiologiae inter leges memoratu dignum est Horatianum illud :"fortes creantur fortibus et bonis." Iuvat igitur Ducis fortissimi et optimi, abhinc annos undecim Doctoris nosfri nominati, heredem dignissimum laurea eadem hodie coronare.

The Right Hon. Visconnt Esher, G.C.V.O., G.C.B., M.A., Trinity College.

Sequitur deinceps iudicis summi, alumni nostri, filius, vir et inter Etonenses et in Collegio nostro maximo educatus, deinde regni totius senatoribus suffragio electis per quinquennium additus, Ducis Devoniae Cancellarii nostri filio, postea Cancellario nostro, fere eodem tempore adiutor acerrimus. Nuper etiam Academiam nostram magnopere adiuvit, et aliorum in nos liberalitatem generosissimam excitavit. Viri huius ductu prospero, aureus ille donorum rivus Academiae nostrae in silvas defluxit; eiusdem auxilio, etiam in clivo quodam saluberrimo salutis templum illud nuper aedificatum est, ubi hereditatis (ut aiunt) leges professor noster novus investigabit, cuius cathedra alumni nostri magni nomine in perpetuum ornabitur, Arthuri Balfour. Ergo, in colle nobis propinquo, a professore nostro, etiam in aliis rerum naturae provinciis, Horatianum illud verum esse comprobabitur :est in iuvencis, est in equis patrum
virtus, neque imbellem feroces
progentrant aquilae columbam.

The Right Hon. Baron Mollton of Bank, M.A., F.R.S., Honorary Fellow of St. John's, and late Fellow of Christ's.

Adsurgit proximus Collegii Divi Ioannis alumnus, vir abhinc annos quadraginta sex in studiis mathematicis locum omnium summum adeptus, qui, Christi in Collegio socius electus, etiam iuris in provincia honorum publicorum ad culmina summa pervenit. Olim in legibus ad scientiam machinalem pertinentibus inclaruit; nuper etiam medicinae de scientia illo die praeclare meritus est, quo experimenta quaedam generis humani saluti necessaria esse luculenter comprobavit. Ergo non modo Archimedis sed etiam Aesculapi alumnis iure optimo erit acceptissimus. Ceterum haec omnia, peritis non ignota, hodie neque (ut Tullius ait) ad vivum resecanda, neque (ut mathe- matici dicunt) ad infinitum producenda. Inter omnes constat iudicem tam conspicuum iuris doctorem hodie merito creari.

\section{Colonel Starling Melix Benson, Master of the Drapers' Company.}

Inter societates illas Londinienses, quae divitiarum amplitudine et liberalitatis laude excellunt, una est quae propterea nostrum omnium animis identidem obversatur, quod non modo agri culturae studiun inter nos magnopere adiuvit, sed etiam, munificentia hodie imprimis memorabili, aedificium novum physiologiae studiis dedicatum nobis donavit. Ut in societatem illam munificam animum nostrum gratum aliquatenus indicemus, societatis totius magistrum titulo nostro libenter decoramus, virum qui, olim inter milites spectandus, linteonum (ut aiunt) in societate liberalissima, pacis in artibus iam dudum floruit. Hodie saltem "cedant arma togae," dum militum tribunum, etiam pacis in artibus praeclarum, purpuris nostra honoris causa vestimus.

\section{Hon. Sc.D.}

Sir William Osler, Bart., M.D., F.R.S., Regius Professor of Medicine, Oxford.

Caritatis vinculo triplici nobiscum est coniunctus medicus illustris, vir inter fratres nostros Canadenses et inter consobrinos nostros transmarinos medicinam praeclare professus, et inter sororis nostrae venerabilis, sororis nostrae Oxoniensis silvas, professoris medicinae regio munere ornatus. Peritis nota sunt ea, quae, aut solus aut cum aliis consociatus, in magna voluminum serie de medicina disputavit. Pluribus loquuntur ea quae de animo aequo, de consiliis ad vitae finem perfectum spectantibus conscripsit. Nobis autem idcirco potissimum dilectus est, quod medicinae, litterarum renascentium in saeculo, studiis devotissimus, inter nosmet ipsos egregie laudavit virum et de Oxoniensibus et de Cantabrigiensibus praeclare meritum, regiae medicorum societatis conditorem illum, Thomam Linacre.

Sir David Ferrier, M.D., F.R.S., Emeritus Professor of Neuropathology, King's College, London.

Progreditur deinceps vir inter Aberdonenses, Edinenses, Heidelbergenses olim educatus, inter Londinienses denique et "neuropathologiam" (ut aiunt) et artem medendi praeclare professus. Viri huius et collegarum eius peregre docentium experimentis didicimus, cerebri duplicis corticem non totum corporis totius motus moderari, sed partem aliam ad aliam corporis partem pertinere; cerebri in parte una videndi sensum, in alia sensum audiendi collocari. Tali autem ex scientia morborum varietates quaedam melius inter sese dignoscuntur, vitaeque humanae dolores multum minuuntur. Abhinc annos quattuor et triginta inter doctores nostros honoris causa libenter numeravimus generis humani amicum illum, Iosephum Lister: hodie vero, saeculo in novo, etiam alium generis humani amicum titulo nostro non minus libenter decoramus.

Sir Edward Schäfer, F.R.S., Professor of Physiology, Edinburgh.

Urbis Edinensis, Athenarum illarum Caledonicarum, Academia ad nos misit physiologiae professorem illustrem, cuius opera, ad histologiae et physiologiae scientiam pertinentia, physiologiae et medicinae studiosis iam dudum cognita sunt. Omnibus autem nota sunt experimenta illa, per quae homines in fluctibus submersi, respiratus artificiosi auxilio, ad vitam revocantur. Olim rex ipse Olympi Aesculapio

NO. 2329, VOL. 93] 
propterea invidisse dicitur, quod, Hippolyto ad vitam revocato, iura Plutonis imminuisset. Nunc autem omnibus penitus persuasum est, nihil quod hominum saluti prosit, summo Patri posse displicere. Non immerito igitur illos in honore habemus, quorum auxilio mortis imperium inter terminos artiores contractum vidimus.

Mr. Ernest Henry Starling, M.D., F.R.S., Professor of Physiology, University College, Lonđon.

Agmen nostrum claudit hodie Universitatis Londiniensis in Collegio quodam illustri professor insignis. Physiologis notum est sanguinis nostri partem quandam e venis quibusdam subtilissimis per corporis telas propinquas textu tenuissimas exsudare, et corpori alimenta quaedam nova ministrare. Viri huius praesertim experimentis sudoris illius ratio universa explicata est, qui etiam vitam corporis iam mortui in corde et pulmonibus conservatam, et partium superstitum motus, investigare potuit. Talium virorum ingenio, vocabulo quodam a lingua Graeca derivato, quod hormone dicitur, res quaedam chemica patefacta est, quae, ex alia corporis parte intima, parti alii stimulos addit, hinc illuc velut nuntia quaedam transmissa. Etiam physiologiae in studio quicquid novi aliunde ad nos advectum est, etiam nobis novos stimulos addit. Ergo etiam hunc virum, rerum exterarum nuntium ad nos advectum, decoramus, qui tot collegas suos non modo industriae et laboris sed etiam gloriae et honoris stimulis concitavit.

\section{THE CARNEGIE FOUNDATION FOR THE ADVANCEMENT OF TEACHING.}

THE annual report of the president of the Carnegie Foundation for the Advancement of Teaching shows a total endowment of $3,06_{5}, 000 l$., and an expenditure for the year ending September 30 , 1913, of $131,686 l$. Of this $103,888 l$. were distributed in retiring allowances to professors, and $16,150 l$. in pensions to their widows. Thirty-three allowances were granted during the year, making the total in force 403 , the average annual payment to an individual being $340 l$. The total distribution from the beginning has been $587,385 l$. The educational work of the foundation was separately endowed in January, 1913, by a gift of $250,000 l$. from $\mathrm{Mr}$. Carnegie through the Carnegie Corporation of New York. This body, which is endowed with $25,000,000 l$. for "the advancement and diffusion of knowledge and understanding," has five ex-officio trustees, of whom one must always be the president of the Carnegie Foundation for the Advancement of Teaching.

In connection with the foundation's work as a centre of information concerning pensions, the president, Mr. H. S. Pritchett, discusses pension systems that are maintained by half a dozen colleges, the development of new systems at Brown University, the Rockefeller Institute, and the American Museum of Natural History, the new federated pension svstem of the English universities, and the proposed system for the clergy of the Episcopal Church. Among pensions for public-school teachers the report discusses the New York City system and the new State system in Massachusetts.

At the Rockefeller Institute for Medical Research the pensions are stipendiary in character, being threequarters of the last annual salary to those retiring at the age of sixty-five, after fifteen years of service. Retirement is also permitted at the earlier age of sixty, after fifteen years of service, the pension in this event being one-half of the last annual salary, plus In per cent. for each year of service in excess of fifteen. These pensions are offered only to members NO. 2320, VOL. 93] and associate members of the institute, of whom there are now twelve. The maximum for retiring allowances is higl , being set at 2000 . The rules repeat the rule of the University of Chicago, that the obligation to pay retiring allowances will be neither greater nor less than the obligation to pay salaries; so that if misfortune shall compel a percentage reduction of salaries, retiring allowances may be reduced in the same proportion."

Much of the report is devoted to the development of the educational work of the foundation into a separate division of educational inquiry. Its recent work includes a study of education in Vermont at the request of the Vermont Educational Commission, of legal education at the request of a committee of the American Bar Association, and of engineering education at the request of a joint committee representing the national engineering societies. Plans for the study of engineering education are now being completed.

The earlier educational work of the foundation is continued in the report by commendation of the present tendency of college entrance requirements toward both elevation and flexibility. The need for further improvement is shown by the fact that only 55 per cent. of the students now in American colleges are high-school graduates. The decrease in the number of medical schools in the country from 162 in I9ro to II $_{5}$ in I9I3, and the rapid improvement of the better schools are commented upon with appreciation. A general study of the problems of the State regulation of higher education is provided.

An interesting tabular statement is provided which sets out the total number of students in 807 universities and colleges in the United States, and also the number of these, who, having passed college entrance examinations and requirements, rank as collegiate students. In the 807 institutions there are in all 330,832 students, of whom 183,089 are students of college grade. In each of ten States there are upwards of 10,000 students registered in these places of higher education, and the following extract from the table shows the number of students of college standing in each case.

\begin{tabular}{|c|c|c|c|c|c|c|}
\hline State & \multicolumn{3}{|c|}{ Institutions } & \multirow{2}{*}{$\begin{array}{c}\text { Total } \\
\text { number of } \\
\text { students } \\
26886\end{array}$} & \multirow[b]{2}{*}{$\ldots$} & \multirow{2}{*}{$\begin{array}{c}\text { Studants } \\
\text { of college } \\
\text { grade } \\
14269\end{array}$} \\
\hline Illinois &. & & & & & \\
\hline New York & $\ldots$ & 32 & $\ldots$ & $242 \mathrm{I} 4$ & $\ldots$ & 19365 \\
\hline Pennsylvania & $\ldots$ & 40 & $\ldots$ & 23633 & $\ldots$ & 13279 \\
\hline Ohio & $\ldots$ & 45 & $\ldots$ & 227 & $\ldots$ & 14 \\
\hline Indiana & $\ldots$ & 25 & $\ldots$ & 14 & $\ldots$ & \\
\hline Massachusetts & $\ldots$ & I7 & .. & & $\ldots$ & 13859 \\
\hline Iowa & $\ldots$ & 40 & .. & 13 & $\ldots$ & 6607 \\
\hline Texas & $\ldots$ & 37 & $\ldots$ & I 2653 & $\ldots$ & 4405 \\
\hline & $\ldots$ & 26 & .. & I 5563 & & \\
\hline California & $\ldots$ & I9 & $\ldots$ & 11376 & $\ldots$ & 7864 \\
\hline
\end{tabular}

There has been in the last five years a marked recrudescence of State activity with regard to higher institutions of learning. In a number of States the president of the State university has been dismissed, whether justly or unjustly, in a peremptory manner. In other States there has been legislation with respect to the differentiation of State institutions. In still others the regulation of degree-granting powers has occupied the attention of legislators. On the whole, the last five years have been distinctly marked by the activity of legislative authorities concerning the State institutions, and by the evidences of some awakening as to the need for the regulation of all higher institutions of learning. Whatever may be the immediate outcome of this movement, it is probably a hopeful sign of the beginning of a successful effort to differentiate State institutions and to bring within fair limits the degree-granting powers of endowed institutions.

The report further presents a study of the financial 